$1-1-2014$

\title{
Estimating water quality effects of conservation practices and grazing land use scenarios
}

Grace L. Wilson

Brent J. Dalzell

David J. Mulla

Toby Dogwiler

Paul M. Porter

Follow this and additional works at: https://bearworks.missouristate.edu/articles-cnas

\section{Recommended Citation}

Wilson, Grace L., Brent J. Dalzell, David J. Mulla, Toby Dogwiler, and Paul M. Porter. "Estimating water quality effects of conservation practices and grazing land use scenarios." Journal of Soil and Water Conservation 69, no. 4 (2014): 330-342.

This article or document was made available through BearWorks, the institutional repository of Missouri State University. The work contained in it may be protected by copyright and require permission of the copyright holder for reuse or redistribution.

For more information, please contact BearWorks@library.missouristate.edu. 
1 Estimating water quality effects of conservation practices and grazing landuse scenarios

4 Abstract: Conservation management practices such as reduced tillage, fertilizer management,

5 and buffer strips, are well-established means by which to control erosion and nutrient losses from

6 fields planted in annual row crops. However, agricultural systems which include perennial plant

7 cover, such as the perennial forages found in grazing systems, may represent an alternative way

8 to reduce these losses. In this study, management intensive rotational grazing (MIRG) was

9 tested as a means by which to improve water quality on highly vulnerable row crop land,

10 compared to more traditional conservation management schemes in the South Branch of the Root

11 River watershed (a karst-influenced watershed in Southeastern Minnesota). The effects of both

12 sets of alternative scenarios were evaluated with a watershed-based modeling approach using the

13 Soil and Water Assessment Tool (SWAT). Alternative conservation management practices

14 included conservation tillage, cover crops, and filter strips. Conversion of row crop production to

15 management intensive rotational grazing of beef cattle was selected to occur on $2.6 \%$ of the total

16 watershed area. Both the conservation management practices and land-use changes were

17 targeted to reduce contributions of sediment and phosphorus loads from cropped upland areas.

18 Watershed-wide implementation of all conservation management practices resulted in the

19 greatest reductions in sediment (52\%) and total phosphorus (28\%) loads from upland crop areas,

20 but had the largest land area requirements to achieve these results. Cover crops or filter strips on

21 areas of high slope also showed large cumulative reductions across the watershed, and also had

22 the greatest reductions per-unit treated area of all conservation management practices. However, 
23 changing land-use from row crop production to pasture for grazing was most effective at

24 reducing total sediment and phosphorus loads on those acres changed, reducing sediment and

25 phosphorus by greater than $85 \%$ on targeted areas. Simulation results indicate that utilizing

26 alternative conservation management practices or MIRG, when targeted to areas of steeper slope

27 (greater than 4\%), could appreciably reduce sediment and phosphorus loads in this watershed,

28 with limited reductions in row crop agriculture acreage.

29 Key Words: alternative land management scenarios - conservation practices - conservation tillage — cover crops — filter strips_-grazing — phosphorus — sediment — Soil and Water Assessment Tool (SWAT)—water quality

\section{Nutrients and sediment originating from agricultural fields in the Upper Midwest have} been attributed to the impairment of both fresh and marine water systems, contaminating drinking water sources and coastal areas (Schulte et al. 2006). Topsoil losses from annually cropped fields can be significant, decreasing the long-term productivity of the land and

37 threatening water resources (Kort et al. 1998; US EPA 2003). Nutrient export from extensively cropped agricultural areas into coastal marine systems has resulted in hypoxic environments and eutrophication of fresh water lakes (Committee on Environment and Natural Resources 2010; Sharpley et al. 2001). Agricultural systems that incorporate perennial vegetation have been

41 shown to reduce nutrient losses and soil erosion leading, to an improvement in water quality

42 (Burkart et al. 2005; Dalzell et al. 2004; Randall et al. 1997; Russelle et al. 2007). However, 43 lack of economic incentives and markets has limited their adoption (Randall and Mulla 2001). 
44 For the U.S. Upper Midwest, cattle production systems that use perennial forages as the primary

45 component of the diet could be an economically viable way to add perennial species to the

46 landscape. However, overuse and continuous grazing of pasture can result in compacted soil,

47 high rates of erosion, and increased nutrient discharge; in the worst cases, the nutrient losses can

48 be greater than for annual cropland (Hubbard et al. 2004). Management intensive rotational

49 grazing systems - where cattle are grazed at high densities for short durations, and time in

50 pasture depends on the vigor of the plant stand - have been found to result in more consistent

51 foliage removal and decrease the amount of bare ground compared to continuous grazing

52 systems in sub-humid climates (Oates et al. 2011), and may reduce some of the harmful impacts

53 of grazing. The Minnesota Natural Resource Conservation Service (NRCS) has identified

54 management intensive rotational grazing as a best management practice, and as a means to

55 manage pastures for improved water quality and decreased soil erosion (MN NRCS 2012).

56 Using rotational grazing systems, where care is taken to avoid over grazing on pastures, can

57 reduce the losses of sediment and phosphorus compared to less intensively managed grazing

58 systems (Sovell et al. 2000; Chaubey et al. 2010; Haan et al. 2006).

59 While grazing may represent a viable way to introduce perennial vegetation onto the landscape,

60 agricultural acreages in the Upper Midwest region are valued for their ability to produce grains

61 and other plant food crops, and converting large areas of land from row crop agriculture into

62 pasture for grazing may not be the most economically feasible option for managing agricultural

63 contributions to water quality problems. Conservation practices such as reduced tillage, edge-of-

64 field filter strips, and winter cover crops are often viewed as likely candidates of initial

65 conservation efforts because they have been shown to be effective at reducing sediment and 
nutrient losses (Mulla et al. 2008), and represent less dramatic management changes for

67 conventional row crop systems (as compared to switching to perennial vegetation).

68 Not all portions of agricultural landscapes contribute sediment and nutrients uniformly to

69

70

\section{1}

72

73

74

75

76

77

78

79

80

81

82

83

84

85

86

receiving surface waters (Jones et al. 2001). In this regard, there may be environmental benefits

in strategically placing conservation management practices on the landscape (Galzki et al. 2011;

Vache et al. 2002), or in transitioning key landscape elements from annual row crops to

perennial pasture and forage production. In this study, we examined the potential influence that conservation management practices (alone or in combination), and changes in land-use from

corn and soybean crop production to pasture for grazing beef cattle, could have on water quality.

The analysis presented here is for a karst influenced agricultural watershed located in

Southeastern Minnesota, the South Branch of the Root River. The objectives were to: 1)

evaluate the effects of conservation practices and conversion of cropland to management intensive grazing of perennial pasture on water quality; and 2) to compare the effectiveness of the conservation practices and conversion of cropland to grazed pasture on altering loads of total sediment and phosphorus in the watershed.

\section{Materials and Methods}

South Branch of the Root River Watershed. The $301.77 \mathrm{~km}^{2}(74,569 \mathrm{ac})$ South Branch of the Root River (SBRR) watershed is a tributary of the Root River, and is located in Fillmore and Mower counties in southeastern Minnesota (figure 1). The western half of the watershed is mostly flat (<4\% slope), while, in contrast, the eastern half of the watershed is characterized by steeper slopes (>4\% slope) with karst geology. Approximately 52\% of the watershed area has 
87 less than $2 \%$ slope, while $10 \%$ of the land has a slope greater than $10 \%$ (figure 1 ). In the eastern

88 portion of the watershed, karst processes in the thinly-mantled carbonate bedrock strongly

89 influence near-surface hydrologic and geomorphic processes, including flow along

90 dissolutionally-enlarged fractures and through conduits (Runkel et al. 2003). As is typical with

91 karst processes, nutrients, sediments, and other contaminants can be quickly cycled between the

92 surface and groundwater realms, often via overland runoff into sinkholes (Tipping et al. 2006).

93 The predominant land-use within the watershed is annual row-crop agriculture, composing $67 \%$

94 of the watershed area. The remainder is mixed land use, composed of hay, forest, range, urban,

95 water and wetlands (figure 1). The western portion of the watershed is almost entirely devoted

96 to corn (Zea mays L.) and soybean (Glycine max L.) production. The eastern portion of the

97 watershed has more acreage in forest, hay, and range, though row crops are the dominant land-

98 cover. Average annual precipitation in the watershed is approximately $84 \mathrm{~cm}$ (33 in; Minnesota

99 State Climatology Office 2011). The average annual temperature is $6^{\circ} \mathrm{C}\left(43^{\circ} \mathrm{F}\right)$, with a normal

100 average temperature during the growing season (April through September) of $18^{\circ} \mathrm{C}\left(64^{\circ} \mathrm{F}\right.$;

101 normals are the 30-year mean from 1971 to 2000; Minnesota State Climatology Office 2011).

102 Soils in the area are mostly well-drained, class B soil types (56\%), with some of those areas

103 being B/D soil types having high water tables (24\%). The outlet of the watershed is located

104 within Forestville State Park, where stream flow was measured daily, and water quality was

105 periodically monitored during the study period. Flow (based on a stage-discharge relationship)

106 and water quality data were collected and maintained by the Minnesota Pollution Control

107 Agency and provided to us for this study. 

calibration and validation were available in the SBRR for a five-year period (2004 to 2008).

110 Monthly sediment and phosphorus loads were estimated by coupling the daily flow values with 111 periodically collected water quality measurements. Water quality samples were collected at a 112 minimum of bi-weekly intervals during baseflow conditions. During stormflow events, grab 113 samples were collected more frequently to attempt to capture the rising and falling of the 114 hydrograph. Sediment loads were measured as total suspended solids and phosphorus was 115 measured as total phosphorus (TP). During the study period from 2004 to 2008, a total of 50 and 116113 sediment and phosphorus samples were collected. Monthly sediment and TP loads were 117 estimated using FLUX (Walker 1996). In FLUX, a regression approach applied to individual 118 daily flows (Method 6) was used to predict series of monthly sediment and TP loading data. 119 Prior to FLUX regression analysis, flow data were divided into three strata based on flow. Strata 120 cutoff values for daily mean flow were set at $2.38,5.71$, and $84.8 \mathrm{~m}^{3} \mathrm{sec}^{-1}$ and were selected to 121 divide available data into low-, mid-, and high-flow conditions. Comparison of observed with 122 regression-predicted values yielded $r^{2}$ values of 0.89 and 0.83 for TP and total suspended solids, 123 respectively.

SWAT Model/Inputs. The Soil and Water Assessment Tool (SWAT) 2005 and 125 ArcSWAT interface were used for simulating water quality effects of the alternative land 126 management scenarios in the SBRR watershed. Daily precipitation and temperature data from 127 October 2004 through December 2008 were obtained from the Spring Valley weather station, 128 located near the center of the watershed but approximately $1.6 \mathrm{~km}$ (1 mile) outside the watershed 129 boundary (there were no rain gauges located within the boundaries of the study watershed). In 
cases where daily precipitation and temperature data were missing, they were substituted with values from the Grand Meadow weather station, located approximately $3.2 \mathrm{~km}$ (2 miles) outside the watershed boundary (this occurred for less than $0.6 \%$ and $0.05 \%$ of precipitation and temperature data, respectively). For watershed-scale hydrologic modeling, model outputs can be especially sensitive to precipitation data and care has been taken to ensure that the closest available data were used in this study. Remaining climate data play a less sensitive role in determining daily water flux and were collected from the closest available weather stations. Wind speed and relative humidity data were obtained from stations in La Crosse, WI (90 km or 56 miles from the study watershed), and Minneapolis, MN (160 km or 99 miles from study watershed), respectively. Measured solar radiation data were provided by the Minnesota Climatology Working Group, located in St. Paul, MN (approximately $160 \mathrm{~km}$ or 99 miles from the study watershed).

A digital elevation model (DEM) with $10 \mathrm{~m}(32.8 \mathrm{ft})$ grid size was used to delineate stream networks, subbasins, and slopes (USGS 2009). County-level soils data were obtained from the Digital Soil Survey Geographic (SSURGO) database (USDA-NRCS 2009). User-defined soils data tables were provided by the SWAT development group at Texas A\&M University. Four of the soil map units present in the SSURGO data were not available in the user-defined soil data tables, and were renamed to match adjacent soils map units that had similar texture and hydrologic groups. Land-use and land-cover data with $30 \mathrm{~m}(98 \mathrm{ft})$ grid size were determined from the 2001 National Land Cover Database (NLCD; MRLC 2001). Some of the smallest land cover classes (those that covered less than $1 \%$ of the watershed area) were aggregated to reduce the number of functional units handled by SWAT. 
152 Stream channel dimensions and hydraulics were measured in 17 representative stream reaches

153 throughout the SBRR watershed. The stream reach surveys were total station-based and

154 followed standard methods (Rosgen 1996; Harrelson et al. 1994) to measure stream cross-

155 sections and longitudinal profiles. Reach selection was based on field reconnaissance and GIS-

156 based analyses of topography, aerial imagery, hydrography, and karst features. Through these

157 analyses stream reaches were selected based on their representativeness of the range of

158 characteristics common throughout the watershed with respect to channel morphology, stream

159 gradient, valley morphology, vegetation, and bed forms. The chosen reaches represented the

160 range of channel types and channel conditions found in the SBRR watershed. Based on the

161 surveyed stream geometry, the following variables were determined for the channels and used to

162 parameterize the SWAT model: average width at the top of the bank, depth from the top of the

163 bank, width-to-depth ratio, longitudinal slope, and the Manning's $n$ value. Additionally, the

164 average bankfull longitudinal slope and the length of the main channel were measured from

165 topographic maps. Baseflow velocity measurements were collected using an acoustic Doppler

166 velocimeter and the wading method of discharge determination (Harrelson et al. 1994). The

167 baseflow Manning's values were calculated by solving the Manning Equation for $n$ based on the

168 values for velocity, slope, area, and wetted perimeter measured during the field surveys.

169 Typically, Manning's $n$ values decrease (i.e., less roughness) as stream stage rises. This is a

170 function of area increasing faster than the wetted perimeter (i.e., increasing hydraulic radius).

171 Nonetheless, factors such as bank vegetation can strongly influence the bankfull roughness and

172 cause it to increase with stage. Our bankfull Manning's $n$ values were constrained based on the 
173 baseflow roughness value, professional judgment, and published guidance (Arcement and 174 Schneider 1989).

175 The hydraulic conductivity of the stream bed values input to SWAT were based on

176 measurements in two of the surveyed stream reaches of the SBRR: near Mystery Cave which is

177 dominated by karst hydrology, and in Etna Creek which is influenced predominantly by non-

178 karst conditions. Determinations of the hydraulic conductivities followed the heat pulse method

179 (Silliman and Booth 1993; Ronan et al. 1998; Dogwiler et al. 2007), and were taken during 180 varying flow conditions. Baseflow discharge measurements used in determining the hydraulic 181 conductivity of the stream bed occurred at Etna Creek and near Mystery Cave, and were $0.21 \mathrm{~m}^{3}$ $182 \mathrm{sec}^{-1}$ and $1.95 \mathrm{~m}^{3} \mathrm{sec}^{-1}$, respectively. In each of the two streams, Onset $\AA$ TidbiTTM temperature 183 loggers programmed to record measurements at five minute intervals were buried at three depths 184 in the stream substrate. The manufacturer-reported accuracy of the temperature data loggers is $185 \pm 0.21^{\circ} \mathrm{C}$ in the temperature range of 0 to $50{ }^{\circ} \mathrm{C}$ with a stability (drift) of $0.1{ }^{\circ} \mathrm{C}$ per year. At the 186 non-karst location they were placed at depths of 2,9 , and $16 \mathrm{~cm}(0.8,3.5$, and $6.3 \mathrm{in})$. At the 187 karst location the temperature loggers were buried at depths of 2,12 , and $22 \mathrm{~cm}(0.8,4.7$, and 8.6 188 in). The differences in logger depths between the two reaches reflect the difficulty of excavating 189 and precisely burying the data loggers in a fast flowing stream. However, the differences in the 190 depths between the sites were not critical so long as the absolute depth differences between the 191 temperature loggers were known. Surface water and air temperatures were also measured at 192 each stream reach and a stage record was collected at the non-karst location using a pressure 193 transducer. The hydraulic conductivity was determined based on tracking diurnal water 194 temperature maximums through the stream substrate. The amount of time for a thermal 
195

196

197

198

199

200

201

202

203

204

205

206

207

208

209

210

211

212

213

214

215

216

maximum to infiltrate from one temperature logger to another deeper temperature logger was

used to determine the hydraulic conductivity (in $\mathrm{cm} \mathrm{hr}^{-1}$ ). A mathematical formula described in Dogwiler et al. (2007) provides compensation to the raw thermal pulse velocity for factors such as the densities and thermal capacities of the substrate sediment and water. The result of this computation is the vertical hydraulic conductivity of the stream sediment. In low-order, gravelbedded streams thermal variations tend to be greatest on sunny days at baseflow conditions (Dogwiler and Wicks 2005; Dogwiler et al. 2007). Thus, the data set was filtered to look exclusively at days comprised of baseflow conditions (i.e., with no significant precipitation). Both data sets cover the period from late May through August 2008 with 49 days of baseflow analyzed at Etna Creek and 55 days at the reach near Mystery Cave. Diurnal temperature ranges at base flow ranged from $1.0^{\circ} \mathrm{C}$ to $7.2^{\circ} \mathrm{C}\left(33.8^{\circ} \mathrm{F}\right.$ to $\left.45^{\circ} \mathrm{F}\right)$ and $1.2^{\circ} \mathrm{C}$ to $5.9^{\circ} \mathrm{C}\left(34^{\circ} \mathrm{F}\right.$ to $\left.43^{\circ} \mathrm{F}\right)$, respectively, at the Etna Creek and Mystery Cave sites. The results for each stream were averaged to yield a hydraulic conductivity that integrates variations in diurnal temperature range, solar radiation, stream flow, and other governing factors. Measured stream physical characteristics and hydrologic conductivity values were applied to the spatially-corresponding stream reaches in the SWAT model.

Baseline Crop Management Practices. Cropping management practices were developed to represent typical crop operations in this watershed. Crop planting and harvesting dates were average values determined from 10 years of weekly crop reports. Typical tillage and fertilizer practices were determined from surveys of local farmers conducted and published by the Minnesota Department of Agriculture (Rasmussen 2003 and 2007). All cropland was in a twoyear rotation of corn and soybean common for the region. Soil management included spring 
217 cultivation and fall plowing. Chisel plow was used on soybean residue while disc plow was used

218 on corn residue. Fertilizer application was split to represent the most common practices

219 occurring throughout the watershed. Phosphorus $(\mathrm{P})$ was applied in the fall and at planting for a

220 total application of $60 \mathrm{~kg} \mathrm{P} \mathrm{ha}^{-1}\left(53 \mathrm{lb} \mathrm{P} \mathrm{ac}^{-1}\right)$. Nitrogen $(\mathrm{N})$ was applied in the fall during field

221 preparation and at planting for a total application of $144 \mathrm{~kg} \mathrm{~N} \mathrm{ha}^{-1}\left(128 \mathrm{lb} \mathrm{N} \mathrm{ac}^{-1}\right)$.

222 Based on the local producer surveys (Rasmussen 2003 and 2007), it was estimated that animal

223 manure was applied to approximately $8 \%$ of cropland in the SBRR during any given year. The

224 major sources of manure applied to crop fields were from swine and dairy operations within the

225 watershed, and were the two sources of manure applied for the baseline scenario. Swine manure

226 was applied to two subbasins in the western portion of the watershed while dairy manure was

227 applied to two subbasins in the north eastern portion of the watershed (figure 1). Since it was not

228 feasible to know the exact location of all manure application in the study area, this was a

229 simplification of actual manure management practices within the SBRR watershed; in actuality,

230 fields receiving manure are more distributed throughout the watershed. The approach used here

231 was based on the general distribution of animals in the watershed and results provided insight

232 into how manure application influenced nutrient losses from row cropped fields in varying

233 portions of the SBRR watershed.

234 A crop management schedule was established such that, in those subbasins receiving swine or 235 dairy manure, manure was applied to every corn acre once in four years on rotation. Manure 236 application was divided between fall (67\%) and spring (33\%) according to the FANMAP (Farm

237 Nutrient Management Assessment Program) surveys (Rasmussen 2003 and 2007). For the 
238 baseline scenario, commercial $\mathrm{N}$ and $\mathrm{P}$ fertilizer rates were not changed in response to manure

239 application (personal communication with MN Dept. of Agriculture staff). This resulted in these

240 fields receiving excess $\mathrm{N}$ and $\mathrm{P}$ once every 4 years. Manure was applied to achieve a rate of 98.8

$241 \mathrm{~kg} \mathrm{P} \mathrm{ha}^{-1}\left(88.2 \mathrm{lb} \mathrm{P} \mathrm{ac}^{-1}\right)$ based on phosphorus application rates reported in the FANMAP survey.

242 Manure N:P ratios were taken from a Minnesota Department of Agriculture fact sheet (1999) and

243 were preserved within the model nutrient database; as a result, manure $\mathrm{N}$ application rates were

244 dependent on the amount of manure required to achieve the estimated manure $\mathrm{P}$ rate and were

245 different for swine and dairy manure.

Calibration and Validation. All model runs occurred for the years 2002-2008; the first

247 two years were included as a warm-up period from which results were not used in order to

248 eliminate model sensitivity to initialization values and allow environmental parameters such as

249 simulated soil moisture to equilibrate to simulated conditions. Following the warm-up period, a

250 five-year simulation period (years 2004-2008) was used to evaluate the model performance and

251 assess baseline and alterative scenarios. The model was manually calibrated with daily and

252 monthly streamflow data and monthly water quality data for the years 2004 to 2005, and

253 validated for the period from 2006 to 2008. SWAT parameters calibrated from defaults are

254 shown in table 1. Karst influenced subbasins were calibrated based on the assumption of

255 stronger contributions from shallow groundwater and shorter delay in groundwater response time

256 compared with non-karst subbasins (table 1; Luhmann 2010). Karst features-including

257 sinkholes, stream sinks, and springs-were obtained from a spatial dataset from the Minnesota

258 Department of Natural Resources (MN DNR 2013). Subbasins were considered karst-influenced

259 based on the occurrence of identified karst features within the subbasin. In general, subbasins 
260 with greater than 15 identified karst features were treated as karst-influenced for the purposes of

261 model simulation (figure 1).

262 Performance of the SWAT model was assessed by comparing monthly values of predicted versus 263 observed flow (mean monthly discharge) and water quality parameters. In addition to comparing 264 mean values for the calibration and validation periods, model performance was evaluated with 265 the Nash-Sutcliffe Efficiency metric (NSE; Nash and Sutcliffe 1970):

$$
E=1-\frac{\sum\left(Y_{o}-Y_{m}\right)^{2}}{\sum\left(Y_{o}-\overline{Y_{o}}\right)^{2}}
$$

267 where $Y_{o}$ is the observed monthly value (discharge or load), $Y_{m}$ is the modeled value of the 268 same parameter, and $\bar{Y}_{o}$ is the mean value of the observed data. NSE values can range from $-\infty$ 269 to 1. Perfect agreement between predicted and observed data results in NSE = 1; an NSE value 270 of 0 indicates that the mean of the model prediction is as accurate as the observed. A value 271 greater than 0.75 for monthly NSE can be considered very good; between 0.65 and 0.75 can be 272 considered good model performance, while a value between 0.5 and 0.65 is considered 273 satisfactory (Moriasi et al. 2007).

Alternative Scenarios. Two sets of alternative scenarios were evaluated for the SBRR watershed. The first set of management practices considered no change in land-use, and that 276 conservation practices typical for the region would be employed on select cropland. Under the 277 second set of alternative scenarios, a portion of the cropland was converted to pasture for 278 management intensive rotational grazing of beef cattle. Each alternative scenario simulated is 279 summarized in table 2. The evaluation for each suite of practices was compared to the result 
280 from the baseline crop management and land-use practices (which describe current row-crop

281 farming practices) to obtain the relative changes in performance of the alternative scenarios.

282

283

284

285

286

287

288

289

290

291

292

293

294

295

296

297

298

299

300

Alternative Management-Row Crops. Chisel and disk tillage practices were replaced with a generic conservation tillage practice, maintaining the use of field cultivators for planting.

The conservation tillage practices were not as deep or well-mixed as conventional practices, allowing for more crop residue to remain on the soil surface, reducing soil erosion. Two conservation tillage scenarios were developed: 1) conservation tillage uniformly distributed across $25 \%$ of the cropland in the watershed (i.e. geography, landscape position, or geology were not considered), and 2) conservation tillage applied to cropland with greater than $4 \%$ slope. The 4\% threshold represents a user-defined break point used in HRU generation. In the study watershed, $8.4 \%$ of row crops are situated on lands with slopes greater than $4 \%$.

A second alternative crop management practice utilized a rye cover crop, simulated on croplands with slope greater than $4 \%$. This practice also had no dairy manure applied on croplands with slope greater than 4\%; manure that would have gone on these areas was redistributed to cropland with slopes less than $4 \%$ so that the total application rate in the watershed was the same as in the baseline scenario. Rye was planted immediately following fall harvest of corn or soybean and allowed to grow in the fall and following spring (as allowed by temperature). Immediately prior to spring field preparation (for corn or soybean), the rye crop was killed and field preparations resumed with primary tillage, field cultivation, and planting.

The effectiveness of filter strips in reducing field losses of sediment and TP was also modeled. A $10 \mathrm{~m}$ (33 ft) wide filter strip was applied to croplands with a slope greater than $4 \%$ based on a 
301 summary of general filter strip guidelines by Lee et al. (2004). Additional scenarios were also 302 developed that were combinations of one or more of the above scenarios, including: croplands 303 with slope greater than $4 \%$ were planted in cover crops, and conservation tillage was used on the 304 remaining cropland; and cover crops and $10 \mathrm{~m}$ filter strips were used on croplands with slope 305 greater than $4 \%$, with conservation tillage used on the remaining cropland areas. Both of these 306 combination scenarios also had no dairy manure applied on croplands with slope greater than $3074 \%$; manure that would have gone on these areas was redistributed to cropland with slopes less 308 than $4 \%$ so that the total application rate in the watershed was the same as in the baseline 309 scenario.

Alternative Land-Use-Grazing. For the grazing land-use (GLU) scenario, a small

311 percentage of cropland under the baseline scenario was converted into pasture for grazing beef

312 cattle. The percent change in land area to be converted from cropland into pasture was based on 313 the results of a deterministic model (Wilson 2012) developed to calculate the area of land needed 314 to produce enough "grass-finished" (perennial forage-fed) beef to satiate the beef demand by a 315 defined population (in this case, the demands of the watershed; Wilson 2012). The land area was 316 calculated based on: 1) the energy needs of the cattle (NRC 1984) and average performance 317 observations for grass-finished cattle; and 2) the energy available from perennial forage crops 318 per unit land area (based on assumptions on cattle diet composition and average yield of 319 perennial forage plants in southeastern Minnesota; Wilson 2012). Based on the results on the 320 deterministic model, the calculated land area was determined to equal $2.6 \%$ of the total 321 watershed area, or approximately $8.10 \mathrm{~km}^{2}(2,001 \mathrm{ac})$. 
322 Because a small area of land was to be converted into pasture, GLU was only applied to two

323 subbasins in the watershed (figure 1), chosen based on their contribution of sediment and TP

324 loads. The pollutant loads from cropland under the baseline simulation were aggregated by

325 subbasins, which were then ranked based on their contribution to the total loads of pollutants

326 calculated under the baseline scenario simulation. Grazing land-use was applied to HRUs in the

327 two subbasins that showed both a high contribution of pollutants, and had a total combined area

328 equal to the target area. Three approaches were then used to target where the land-use change

329 was applied within those subbasins: 1) in areas of high slope (steep approach), 2) in areas with

330 low crop productivity index (CPI) values (CPI approach), and 3) randomly distributed (random

331 approach).

332 In the steep approach, hydrologic response units (HRUs) on cropland with greater than $4 \%$

333 slopes were targeted for grazing land-use. In the CPI approach, locations were targeted based on

334 the potential yields of corn production in the SBRR watershed based on soil characteristics. The

335 CPI index ranges from 0 to 100, with 0 indicating very low expected corn yield and 100

336 indicating very high yields. Within the two targeted subbasins, areas with the lowest expected

337 corn yield had GLU implemented. CPI data obtained in raster format from the Minnesota

338 Geospatial Information Office (Minnesota Geospatial Information Office 2011) was joined to the

339 HRU data using ESRI ArcMap ${ }^{\mathrm{TM}}$ to identify HRUs with the lowest CPI values. The CPI values

340 for GLU HRUs ranged from 15 to 78. The random approach was to locate pasture randomly on

341 cropland within the targeted subbasins. The HRUs which corresponded to cropland under

342 baseline conditions were selected with a random number generator (MS Excel $\left.{ }^{\mathrm{TM}}\right)$. In all three

343 approaches, HRUs were chosen so that the total area undergoing land-use change was 
344 approximately equal to the target area $\left(8.10 \mathrm{~km}^{2}\right)$. While the target area of land transformed was 345 the same for all three approaches $\left(8.10 \mathrm{~km}^{2}\right)$, the actual geographical area was not exactly the 346 same due to the fact that not all HRUs were the same size. In order to compare the outcomes of 347 the three approaches, final sediment and TP outputs were normalized by area.

348 Winter pasture was used as the modeled vegetation-type for the grazing land-use scenarios. All 349 plant growth parameters in SWAT were left at defaults, except the heat units to reach maturity, 350 which were decreased to 1000 in order for the modeled plant growth to more closely match 351 expected values. SWAT-modeled evapotranspiration (ET) for winter pasture was compared 352 against recorded ET rates in grasslands in the Upper Midwest of the United States to ensure that 353 simulated plant growth and water-use was realistic for the region. Average ET for grasslands 354 were obtained from water vapor flux data from the AmeriFlux network (AmeriFlux 2012) and 355 synthesized for sites in the Upper Midwest by taking available data collected in 30-minute 356 intervals and computing daily average values. Daily values from multiple years were averaged to 357 compute annual averages. The calculated average annual ET for grassland in Illinois and South 358 Dakota were 636 and 703 mm, respectively. Average modeled ET for the GLU HRUs was 687 $359 \mathrm{~mm}$ year $^{-1}$, within the range of ET reported for grassland cover in the Upper Mississippi River 360 Basin.

361 The GLU scenarios assumed management intensive rotational grazing (MIRG) where cattle 362 would be rotated through pastures based on plant vigor and height, in order to avoid overgrazing 363 and allowing for recovery periods for the plants. In order to simplify the GLU scenarios in 364 SWAT, key inputs for SWAT grazing setup — biomass removed and manure applied during 
grazing - were averaged over the course of the grazing season. Setting up a true management intensive rotational grazing system in SWAT would have been difficult, since the length of time

367 the cattle spend on pasture depends on examination of plant vigor in the field. Rotational 368 grazing was scheduled to begin on May 1 every year and continue for 184 days, ending October

369 31. The herbage removal rate per unit area on grazing land was equal to $18 \mathrm{~kg} \mathrm{ha}^{-1} \mathrm{~d}^{-1}\left(16 \mathrm{lb}^{-1}\right.$ $370 \mathrm{~d}^{-1}$ ). The initial assumptions on cattle feed intake assumed high quality forage (high in protein 371 and energy content), so this rate of consumption was assumed to represent in a stocking rate of $3721,064 \mathrm{~kg}(2,346 \mathrm{lb})$ cattle live-weight per hectare per day (Wilson 2012). Trampling of 373 vegetation during grazing was considered to equal $20 \%$ of the herbage removed during grazing 374 (Gerrish 2002). No minimum threshold for plant height was set for grazing to occur, however 375 based on the yield for winter pasture simulated in SWAT there was enough biomass grown to 376 meet cattle feed intake. Manure (dung and urine) from the grazing cattle was deposited at a rate 377 of $6.6 \mathrm{~kg}$ dry matter $(\mathrm{DM}) \mathrm{ha}^{-1} \mathrm{~d}^{-1}\left(5.9 \mathrm{lb} \mathrm{DM} \mathrm{ac}^{-1} \mathrm{~d}^{-1}\right)$, based on cattle growth and population 378 assumptions described in Wilson (2012) and using the ASAE Manure Production and 379 Characteristics Standard (ASAE 2005). No additional fertilizer or manure was applied to 380 pasture.

381 Since the rotational grazing system assumed a vigorous plant stand in the pasture (Oates et al. 382 2011), the Soil Conservation Service (SCS) curve numbers for HRUs converted to GLU were 383 chosen to reflect good hydrologic conditions; the definition of good hydrologic soil conditions 384 was greater than $75 \%$ ground cover and lightly or only occasional grazed (Neitsch 2005).

385 Grazing at high cattle stocking rates (as frequently seen with management intensive rotational 386 grazing) has been shown to alter soil physical properties, resulting in soil compaction (Warren et 
al. 1986), reduced infiltration (Kumar et al. 2012), and changes in soil bulk density (Daniel et al. 2002). To account for these changes, the SCS curve number for HRUs converted to GLU were adjusted to reflect a soil type with greater runoff potential. Curve numbers were chosen to be intermediate to the soil type and one step down, i.e. a B soil group was set to have its curve number equal to the intermediate value of B and C hydrologic soil groups for pasture in good

392 hydrologic condition.

393 Grazing cattle were assumed to be housed under shelter during the winter, with their manure 394 collected and applied to corn acreages the following spring, as is common practice for pasture395 based beef producers in the region. The study assumed an application rate of $135 \mathrm{~kg} \mathrm{~N} \mathrm{ha}^{-1}$ (121 $396 \mathrm{lbs} \mathrm{N} \mathrm{ac}^{-1}$ ), typical to that applied in the watershed. Winter manure produced by cattle in the 397 SBRR watershed contained 56,234 kg N (123,975 lb N; Wilson 2012). Based on N losses during 398 manure storage in the region, it was assumed that $50 \%$ of the total $\mathrm{N}$ in the manure was available 399 for application in the spring (Rasmussen 2007), resulting in $28,117 \mathrm{~kg} \mathrm{~N}(61,987 \mathrm{lb} \mathrm{N})$ for corn. 400 To achieve an application rate of $135 \mathrm{~kg} \mathrm{~N} \mathrm{ha}^{-1}\left(120.5 \mathrm{lb} \mathrm{N} \mathrm{ac}^{-1}\right), 209$ ha (516 ac) needed to have 401 manure applied. This acreage was split between corn acreage in the two targeted subbasins. 402 Cattle manure was applied every spring at a rate of $13,500 \mathrm{~kg} \mathrm{DM} \mathrm{ha}^{-1}\left(12,049 \mathrm{lb} \mathrm{DM} \mathrm{ac}^{-1}\right)$.

\section{Results and Discussion}

Calibration and Validation. Observed and simulated monthly streamflow, sediment

405 yield, and TP stream loads during the calibration (2004 to 2005) and validation (2006 to 2008)

406 periods are shown in figure 2. Observed data were not available for all months and are indicated 407 by gaps in the observed data (usually winter months when average temperatures were below 
$\left.408 \quad 0^{\circ} \mathrm{C}\right)$. Months lacking observed data do not factor into calculations of model performance.

409 Mean monthly calibration and validation results are shown in table 3, along with monthly

410 estimates of model performance. For predicting sediment and TP loads, the model performed

411 better during the validation period than during the calibration period, though overall the model-

412 predicted values matched the observed data in general magnitude and timing (figure 2). Given

413 that the goal of this study was to compare the relative differences in pollutant reduction rates, the

414 results of the calibration and validation were considered acceptable. Notable months of

415 disagreement between observed and predicted data occur during the validation period in August

4162007 and June 2008. Both of these months were characterized by large precipitation events and

417 multiple events over the course of several days. Compared against the 10-year mean from 1999-

4182009 , county precipitation for August 2007 and June 2008 were 304\% and 148\% greater than

419 average values, respectively. More importantly, summer precipitation events in the Upper

420 Midwest are often associated with convective thunderstorms that can be very intense, but

421 isolated and difficult to characterize with rain gauge data. The available precipitation data likely

422 did not capture the spatial availability that occurred during these precipitation events, leading to

423 disagreement between observed and predicted values during these months. Factors that account

424 for stream bank erosion were not considered for this study so the model does not treat this as a

425 sediment source. Previous work on a watershed sediment budget in the same region showed that

426 erosion from stream banks is relatively minor compared to net upland erosion (Trimble 1999).

427 Baseline Conditions. For the 5-year (years 2004 to 2008) evaluation period simulated,

428 average annual precipitation was $1020.7 \mathrm{~mm}$ (40.2 in). Under baseline conditions during the

429 evaluation period, evapotranspiration removed $70 \%$ of the annual precipitation from the 
watershed, with $25 \%$ of the average precipitation contributing to water yield at the outlet. Of the total water that reached the outlet of the watershed, the majority $(59 \%)$ was from groundwater flow, $17.3 \%$ from tile flow, $14.3 \%$ from surface runoff, and $9.2 \%$ from lateral soil flow. The strong groundwater component is a reflection of the karst influence in this basin. By way of comparison, the water budget for an agricultural watershed located in the Minnesota River Basin (without karst influence) showed that groundwater flow contributed just $0.4 \%$ of the water yield while tile flow, surface runoff, and lateral soil flow contributed 63.1, 23.0, and 13.6\%, respectively (Dalzell et al. 2012).

Sediment and TP loads under baseline conditions were calculated based on cumulative loads delivered to HRU outlets. Over the 5-year evaluation period, average annual loads of sediment and TP from all HRU outlets in the watershed were 0.89 tons ha ${ }^{-1}\left(0.4 \mathrm{tn} \mathrm{ac}^{-1}\right)$ and $0.73 \mathrm{~kg} \mathrm{ha}^{-1}$ $\left(0.65 \mathrm{lb} \mathrm{ac}^{-1}\right)$, respectively. A small number of HRUs were responsible for a large proportion of the annual load of sediment and TP; $25 \%$ of the total watershed area was responsible for $75 \%$ of the total sediment load, and 64\% of TP loads (figure 3). HRUs considered steep cropland-those with annual crops on slopes greater than 4\%-contributed loads of sediment and TP disproportionate to their area. Annually, these HRUs contributed 51\% of the total sediment loads and $38 \%$ of TP loads, even though they accounted for only $8.4 \%$ of the total land area. Sediment Reduction-Alternative Scenarios. Figure 4 shows the change in sediment loads with the alternative scenarios relative to the baseline scenario. These rates were calculated as the average annual sediment loads delivered to the HRU outlets (during the five year simulation period), and reported as both a function of the total watershed area (cumulative 
451 sediment loads from all HRU outlets in the watershed) and as a function of treated area

452 (sediment loads from treated HRUs only). Alternative conservation management practices

453 scenarios that targeted landscape elements contributing the greatest sources of sediment were,

454 not surprisingly, the most effective at reducing it. Cover crops and filter strips on croplands with

455 slopes steeper than $4 \%$ reduced cumulative HRU loads of sediment in the watershed by 28 and

$45637 \%$, respectively. Targeted conservation tillage was less effective, reducing the cumulative

457 sediment loads to HRU outlets in the watershed by only $7 \%$. The greatest reduction in sediment

458 was seen when a combined approach was simulated, which employed both cover crops and filter

459 strips on croplands steeper than 4\%, along with conservation tillage on all remaining cropland.

460 Under this management practice, the cumulative sediment load in the watershed was reduced by

$46153 \%$. However, this practice also involved the greatest fraction of the watershed area (67\% of

462 watershed area).

463 Of the conservation management practices, reductions in sediment loads as a function of only

464 treated areas were greatest with cover crops or filter strips on slopes greater than 4\%; on just the

$4658.4 \%$ of cropland that had cover crops or filter strips applied, sediment was reduced by $55 \%$

466 (cover crops) and 75\% (filter strips) compared to the loads from those HRUs under baseline

467 management practices (figure 4). These simulated reductions of sediment per-unit treated area

468 are consistent with reported reductions in field losses of sediment. Rye and oat cover crops

469 following no-till soybean in Iowa reduced rill erosion by $79 \%$ and $49 \%$, respectively (Kaspar et

470 al. 2001). Also in Iowa, Lee et al. (2000) found that a 7.1m grass buffer on cropland with

471 average slope of 5\% resulted in $70 \%$ reduction of sediment lost from the field; while Robinson et

472 al. (1996) reported 85\% sediment trapping efficiency for $9.1 \mathrm{~m}$ buffers boarding cropland with 
$47312 \%$ slope. The alternative management scenarios evaluated here focus on practices that occur

474 in (or adjacent to) crop fields-scenarios for which SWAT is well suited. There are additional

475 measures that can be employed to reduce sediment loads in SBRR streams that focus on

476 structural practices such as terracing and construction of earthen dams. These structural

477 practices were not evaluated in the present study.

478 Implementation of the GLU scenarios using all three targeted approaches also resulted in

479 cumulative reductions in HRU loads in the watershed, reducing annual HRU loads of sediment

480 by $12 \%$ under the steep approach, $8 \%$ with the CPI approach, and $6 \%$ with the random approach

481 (figure 4). Compared to the alternative conservation management practices, the GLU scenarios

482 resulted in relatively small reductions in HRU loads of sediment at the watershed level; however

483 the GLU scenarios did result in the largest reductions in sediment loads on a per-unit treated area

484 basis (figure 4). For only those HRUs which were converted from cropland to grazing, sediment

485 loads were reduced by $86 \%$ with the steep approach, $85 \%$ with the CPI approach, and $87 \%$ with

486 the random approach. These large reductions per-unit treated area are primarily a result of the

487 land-cover factor in the Modified Universal Soil Loss Equation (MUSLE). MUSLE is used in

488 SWAT to calculate sediment yield in each HRU as a function of surface runoff, soil type, slope,

489 and land-cover (Neitsch et al. 2005). For those HRUs which were converted from row crops to

490 pasture for grazing, two of these factors— surface runoff and land-cover cover—changed

491 between the baseline and GLU scenarios. Surface runoff accounted for a greater percentage of

492 the total precipitation for GLU HRUs compared to the baseline. Higher runoff volumes would

493 be expected to increase the sediment yield from the GLU HRUs. However, the overall reduction

494 in sediment yield seen in model simulations is due to the lower value of the land-cover factor 
used in MUSLE, a result of having greater plant residue and cover throughout the entire year with the GLU scenarios.

Phosphorus Reduction-Alternative Scenarios. In the alternative conservation management scenarios where dairy manure was not applied to slopes steeper than $4 \%$ (CovCrop4, CovCrop4-ConsTill100, and CovCropFilter4-ConsTill100), there was approximately a $49 \%$ increase in rates of dairy manure application (during the year it was applied) on fields with slopes less than $4 \%$ (because the total amount of manure applied in the watershed was held constant compared to the baseline scenario). Simulated manure application rates were already in excess of plant requirements and this redistribution of manure could result in increased nutrient loss from those fields receiving additional manure. (Manure was applied in this way based on the assumption that it was not likely to be transported longer distances to additional fields due to the logistics and cost of manure transportation.)

Figure 5 shows the change in TP loads with the alternative conservation management scenarios relative to the baseline scenario. These rates were calculated as the average annual loads delivered to the HRU outlets (during the five year simulation period), and reported as both a function of the total watershed area (cumulative sediment loads from all HRU outlets in the watershed) and as a function of treated area (sediment loads from treated HRUs only). Similar to the simulation results for sediment loads, large reductions in loads of TP occurred with cover crops or vegetated filter strips on croplands with slopes steeper than $4 \%$. These practices (in addition to manure redistribution for the cover crops scenario) resulted in cumulative reductions of TP loads in the watershed by 17 and 27\%, respectively. The combination of cover crops and 
516 filter strips with conservation tillage on remaining cropland achieved the greatest reduction in

517 cumulative HRU loads of TP loads in the watershed (28\%). In contrast to the sediment results,

518 conservation tillage did little to reduce TP loss and actually increased it in some scenarios (figure

519 5). This is the result of crop residue decomposition within the SWAT model framework. Within

520 the model, less efficient (and more shallow) tillage results in a greater proportion of crop residue

521 remaining on the soil surface where it is allowed to decompose and transition from organic to

522 mineral P; thus increasing the potential losses of soluble P from farm fields, even though

523 sediment erosion is diminished. SWAT-predicted losses of soluble P are minor and generally

524 comprised less than $8 \%$ of the total predicted P losses for all scenarios.

525 Implementation of the GLU scenarios also resulted in reductions in annual cumulative HRU

526 loads of TP in the watershed, with a 10\% reduction in TP loads under the steep approach, $7 \%$

527 with the CPI approach, and $4 \%$ with the random approach (figure 5). The decision to use a

528 seasonal average of manure deposition could result in simulated TP results differing from actual

529 field conditions, where manure would be concentrated in areas which were being actively

530 grazed. However, the majority (>90\%) of predicted TP loss for this watershed is caused through

531 organic and mineral attachment of phosphorus to sediment in surface runoff. By maintaining

532 adequate plant cover, these losses should be minimal. Similar results have been reported in field

533 studies of grazing in Iowa; Haan et al. (2006) found that surface runoff from pastures which were

534 managed to maintain adequate residual forage cover did not contribute greater sediment or TP to

535 surface waters than an un-grazed grassland. 
536 Reductions in TP loads as a function of only treated area followed a similar pattern to sediment

537 loads. On the $2.6 \%$ of land that was changed from cropland to grazing, TP loads from those

538 HRU outlets were decreased by $87 \%$ under the steep GLU approach and $86 \%$ for both the CPI

539 and random approaches - the largest reductions of TP on a per-unit treated area basis in the

540 study. The alternative management practice showing the greatest reduction in TP per-unit

541 treated area were filter strips and cover crops placed on croplands with slope greater than $4 \%$,

542 with a reduction of $73 \%$ and $44 \%$ on the treated acres, respectively. These simulated reductions

543 in TP with cover crops and filter strips are consistent with reduction in reported field losses of

544 TP. Under simulated rainfall, Lee et al. (2000) found a 7.1m grass buffer on 5\% slope removed

$54572 \%$ of TP, while cover crops have been shown to decrease TP losses between 54 to $94 \%$

546 (Kaspar et al. 2008).

548 Summary and Conclusions

549 Simulation results of baseline watershed land-use and management conditions indicate that 550 cropland on areas of high slope (greater than 4\%) in the SBRR watershed contribute loads of 551 sediments and phosphorus disproportional to their area, with $8.4 \%$ of the area of the watershed 552 contributing $51 \%$ of total sediment loads and $38 \%$ of TP loads. Alternative conservation 553 management practices that targeted croplands on areas of high slope were most effective at 554 reducing loads of sediment and TP. The practice most effective at reducing losses across the 555 watershed was the combination of filter strips and cover crops on croplands with slope greater 556 than $4 \%$ with conservation tillage on all remaining cropland, resulting in sediment and TP loss 
557 reductions of $52 \%$ and $28 \%$, respectively. However, in order to achieve these results, a large

558 fraction $(67 \%)$ of the total watershed land area needed to be utilizing a conservation management

559 practice. In contrast, when either cover crops or filter strips were targeted to the $8.4 \%$ of the

560 watershed with cropland areas on a slope greater than $4 \%$, cumulative sediment loads for the

561 watershed were reduced by $37 \%$ and $28 \%$, and TP loads were reduced by $27 \%$ and $17 \%$,

562 respectively. Additionally, on a per treated area basis, filter strips or cover crops reduced

563 simulated sediment loads by $73 \%$ and $55 \%$, respectively, and TP loads by $73 \%$ and $44 \%$,

564 respectively. Given these high reductions in loads per-unit treated area, as well per the entire

565 watershed area, these two practices are the most effective conservation management treatment

566 with regard to achieving the largest reductions of sediment and TP while being needed on

567 relatively few acres.

568 Changing land-use from row crop agriculture to grazed pasture resulted in the greatest reductions

569 in sediment and TP per-unit treated area in the study, reducing both sediment and TP loads by

570 over $85 \%$, regardless of placement strategy. Additionally, when targeted to areas of high slope

571 the small $(2.6 \%)$ reduction in cropland area in favor of pasture also resulted in comparatively

572 large reductions in sediment (12\%) and TP (10\%) loads across the watershed. However, while

573 the reductions in sediment and TP in the watershed are four times greater than the area of land

574 converted from cropland to pasture, the overall reduction in the watershed was smaller than for

575 other conservation management strategies (such as cover crops or filter strips on croplands with 576 slopes greater than $4 \%$ ). 
577 The results of this study indicate that converting land-use from row crop production to highly

578 managed grazed pasture may be an effective way to decrease sediment and TP loads from the

579 most vulnerable (i.e. highly sloped) land areas in the SBRR watershed. However, these

580 reductions have a relatively small effect on the cumulative loads of sediment and TP over the

581 entire watershed. Further reductions could be observed if pasture was increased to cover a

582 greater percentage of the watershed area. Large scale conversion of row crop agriculture in this

583 region is unrealistic; however, a small conversion, as used in this study, may be a feasible target.

584 Of the conservation management practices, conservation tillage on its own, even when targeted

585 to vulnerable areas, is not a very efficient way to control loads of sediment and TP in this

586 watershed, especially compared to the reductions seen when these same land areas have

587 management practices such as cover crops or filter strips applied. Combinations of conservation

588 tillage, cover crops and filter strips are the most effective at reducing loads of sediment and TP,

589 though conservation management practices need to be applied to a large fraction of the total land

590 area. In this regard, the most effective means to reduce loads of sediment and TP is in targeting

591 cover crops and filter strips toward areas with slopes greater than $4 \%$. Data from this study will

592 be useful in helping water quality professionals assess whether changes in agricultural land use

593 or management may be a viable part of moving toward water quality goals while still

594 maintaining a working landscape. 


\section{References}

Arcement, G.J. and V.R. Schneider. 1989. Guide for selecting Manning's roughness coefficients for natural channels and flood plains. United States Geological Survey water-supply paper 2339. Denver, CO: U.S. Geological Survey.

AmeriFlux. 2012. Water vapor flux data. http://public.ornl.gov/ameriflux/. Accessed 2012 January 4.

ASAE (American Society of Agricultural Engineers). 2005. Manure production and characteristics. ASAE Standard D384.2 MAR2005. St. Joseph, MI: American Society of Agricultural and Biological Engineers.

Burkart, M., D. James, M. Liebman, and C. Herndl. 2005. Impacts of integrated crop-livestock systems on nitrogen dynamics and soil erosion in Western Iowa watersheds. Journal of Geophysical Research 110:G01009.

Chaubey, I., L. Chiang, M.W. Gitau, and S. Mohamed. 2010. Effectiveness of best management practices in improving water quality in a pasture-dominated watershed. Journal of Soil and Water Conservation 65(6):424-437.

Committee on Environment and Natural Resources. 2010. Scientific assessment of hypoxia in U.S. coastal waters. Washington, DC: Interagency working group on harmful algal blooms, hypoxia and human health of the Joint Subcommittee on Ocean Science and Technology.

Dalzell, B.J., P.H. Gowda, and D.J. Mulla. 2004. Modeling sediment and phosphorus losses in an agricultural watershed to meet TMDLs. Journal of American Water Resources Association 40(2):533-543.

Dalzell, B.J., D. Pennington, S. Polasky, D.J. Mulla, S. Taff, and E. Nelson. 2012. Lake Pepin watershed full cost accounting project. Final report prepared for the Minnesota Pollution Control Agency. Minneapolis, Minnesota: University of Minnesota.

Daniel, J.A., K. Potter, W. Altom, H. Aljoe, R. Stevens. 2002. Long-term grazing density impacts on soil compaction. Transactions of the ASAE 45(6):1911-1915.

Dogwiler, T., and C.M Wicks. 2006. Thermal variations in the hyporheic zone of a karst stream. International Journal of Speleology 35(2):59-66.

Dogwiler, T., C.M. Wicks, and E. Jenzen. 2007. An assessment of the applicability of the heat pulse method toward the determination of infiltration rates in karst losing-stream reaches. Journal of Cave and Karst Studies 69(2):237-242. 
Galzki, J., A.S. Birr and D.J. Mulla. 2011. Identifying critical agricultural areas with 3-meter LiDAR elevation data for precision conservation. Journal of Soil and Water Conservation 66(6):423-430.

Gerrish, J. 2002. The meaning and significance of utilization rate. University of Missouri Forage Systems Update 11(3). Linneus, MO: University of Missouri Forage Systems Research Center. http://aes.missouri.edu/fsrc/news/archives/n102v11n3a.stm. Accessed 2013 March

Haan, M.M., J.R. Russell, W.J. Powers, J.L. Kovar, and J.L. Benning. 2006. Grazing management effects on sediment and phosphorus is surface runoff. Rangeland Ecology and Management 59(6):607-615.

Harrelson, C.C., C.L. Rawlins, and J.P. Potyondy. 1994. Stream channel reference sites: An illustrated guide to field technique. USDA Forest Service General Technical Report RM245. Fort Collins, CO: U.S. Department of Agriculture, Forest Service, Rocky Mountain Forest and Range Experiment Station.

Hubbard, R., G.L. Newton, and G.M. Hill. 2004. Water quality and the grazing animal. Journal of Animal Science 82(13):E255-E263.

Jones, K.B., A.C. Neale, M.S. Nash, R.D. Van Remortel, J.D. Wickham, K.H. Riitters, and R.V. O'Neill. 2001. Predicting nutrient and sediment loadings to streams from landscape metrics: A multiple watershed study from the United States Mid-Atlantic region. Landscape Ecology 16(4):301-312.

Kaspar, T.C., J.K. Radke, and J.M. Laflen. 2001. Small grain cover crops and wheel traffic effects on infiltration, runoff, and erosion. Journal of Soil and Water Conservation 56(2):160-164.

Kaspar, T.C., E.J. Kladivko, J.W. Singer, S. Morse, and D.R. Mutch. 2008. Potential and limitations of cover crops, living mulches, and perennials to reduce nutrient losses to water sources from agricultural fields in the Upper Mississippi River Basin. In UMRSHNC (Upper Mississippi river Sub-basin Hypoxia Nutrient Committee) Final Report: Gulf Hypoxia and Local Water Quality Concerns Workshop, 127-148. St. Joseph, Michigan. American Society of Agricultural and Biological Engineers.

Kort, J., M. Collins, and D. Ditsch. 1998. A review of soil erosion potential associated with biomass crops. Biomass Bioenergy 14(4):351-359.

Kumar, S., S.H. Anderson, R.P. Udawatta, R.L. Kallenbach. 2012. Water infiltration influenced by agroforestry and grass buffers for a grazed pasture system. Agroforestry Systems 84(3):325-335.

Lee, K.H., T.M. Isenhart, R.C. Schultz, and S.K. Mickelson. 2000. Multispecies riparian buffers trap sediment and nutrients during rainfall simulation. Journal of Environmental Quality 29(4):1200-1205. 
Lee, P., C. Smyth, S. Boutin. 2004. Quantitative review of riparian buffer width guidelines from Canada and the United States. Journal of Environmental Management 70(2):165-180.

Luhmann, A.J., M.D. Covington, A.J, Peters, S.C. Alexander, C.T. Anger, J.A. Green, A.C. Runkel, and E.C. Alexander. 2011. Classification of thermal patterns at karst springs and cave streams. Ground Water 49(3):324-335.

MDA (Minnesota Department of Agriculture). 1999. Fact Sheet: Useful Nutrient Management Data. http://www.mda.state.mn.us/news/publications/chemfert/usefulnutrmgmtdata.pdf. Accessed 2013 March.

MN DNR (Minnesota Department of Natural Resources). 2013. Karst feature inventory points. http://deli.dnr.state.mn.us/data_search.html. Accessed 2013 March

Minnesota Geospatial Information Office. 2011. Crop productivity index ratings for Minnesota. http://www.mngeo.state.mn.us/chouse/soil_cpi.html. Accessed 2012 January 4.

MN NRCS (Minnesota National Resources Conservation Services). 2012. Prescribed Grazing, conservation practice standard 528. St. Paul, MN: Minnesota National Resources Conservation Services. http://efotg.sc.egov.usda.gov/references/public/MN/528mn.pdf. Accessed 2013 May.

Minnesota State Climatology Office. 2011. Minnesota climatology working group: Summaries and publications. http://climate.umn.edu/doc/online_resources.htm. Accessed 2011 December 8.

Moriasi, D.N., J.G. Arnold, M.W. Van Liew, R.L. Bingner, R.D. Harmel, and T. Veith. 2007. Model evaluation guidelines for systematic quantification of accuracy in watershed simulations. Transactions of the ASABE 50(3):885-900.

MRLC (Multi-resolution Land Characterisitcs Consortium). 2001. 2001 Land Use/Land Cover Data. http://www.mrlc.gov/index.php. Accessed March 2013.

Mulla, D.J., A.S. Birr, N.R. Kitchen, and M.B. David. 2008. Limitations of evaluating the effectiveness of agricultural management practices at reducing nutrient losses to surface waters. In UMRSHNC (Upper Mississippi river Sub-basin Hypoxia Nutrient Committee) Final Report: Gulf Hypoxia and Local Water Quality Concerns Workshop, 189-212. St. Joseph, Michigan. American Society of Agricultural and Biological Engineers.

Nash, J.E., and J.V. Sutcliffe. 1970. River flow forecasting through conceptual models part I-A discussion of principles. Journal of Hydrology 10(3):282-290.

NRC (National Research Council (US)). Subcommittee on Beef Cattle Nutrition. 1984. Nutrient requirements of beef cattle. Washington, DC: National Academies Press. 
Neitsch, S.L., J.G. Arnold, J.R. Kiniry, and J.R. Williams. 2005. Soil and water assessment tool theoretical documentation, version 2005. Temple, TX: Grassland, Soil and Water Research Laboratory and Blackland Research Center.

Oates, L.G., D.J. Undersander, C. Gratton, M.M. Bell, and R.D. Jackson. 2011. Managementintensive rotational grazing enhances forage production and quality of subhumid coolseason pastures. Crop Science 51(2):892-901.

Randall, G.W., and D.J. Mulla. 2001. Nitrate nitrogen in surface waters as influenced by climatic conditions and agricultural practices. Journal of Environmental Quality 30(2):337-344.

Randall, G.W., D.R. Huggins, M.P. Russelle, D.J. Fuchs, W.W. Nelson, and J.L. Anderson. 1997. Nitrate losses through subsurface tile drainage in CRP, alfalfa, and row crop systems. Journal of Environmental Quality 26(5):1240-1247.

Rasmussen, D. 2003. Nutrient management assessment of producers: South Branch of the Root River. St. Paul, MN: Minnesota Department of Agriculture. http://www.mda.state.mn.us/protecting/soilprotection/fanmap.aspx.

Rasmussen, D. 2007. Nutrient management assessment of producers: South Branch of the Root River. St. Paul, MN: Minnesota Department of Agriculture. http://www.mda.state.mn.us/protecting/soilprotection/fanmap.aspx.

Robinson, C.A., M. Ghaffarzadeh, and R.M. Cruse. 1996. Vegetative filter strip effects on sediment concentration in cropland runoff. Journal of Soil and Water Conservation 51(3):227-230.

Ronan, A.D., D.E. Prudic, C.E. Thodal, and J. Constantz. 1998. Field study and simulation of diurnal temperature effects on infiltration and variably saturated flow beneath an ephemeral stream. Water Resources Research 34(9):2137-2153.

Rosgen, D. 1996. Applied River Morphology, $2^{\text {nd }}$ ed. Pagosa Springs, CO: Wildland Hydrology.

Runkel, A.C., E.C. Alexander, Jr., J.H. Mossler, R.G. Tipping, J.A. Green, and S.C. Alexander. 2003. Hydrology of the Paleozoic Bedrock in Southeastern Minnesota. Minnesota Geological Survey Report of Investigations 61, St. Paul, MN: Minnesota Geological Survey.

Russelle, M.P., M.H. Entz, and A.J. Franzluebbers. 2007. Reconsidering integrated croplivestock systems in North America. Agronomy Journal 99(2):325-334.

Schulte, L.A., H. Asbjornsen, M. Liebman, and T.R. Crow. 2006. Agroecosystem restoration through strategic integration of perennials. Journal of Soil and Water Conservation 61(6):164A-169A. 
Sharpley, A.N., R.W. McDowell, and P.J.A. Kleinman. 2001. Phosphorus loss from land to water: Integrating agricultural and environmental management. Plant and Soil 237(2):287307.

Sovell, L.A., B. Vondracek, J.A. Frost, and K.G. Mumford. 2000. Impacts of rotational grazing and riparian buffers on physicochemical and biological characteristics of Southeastern Minnesota, USA, streams. Environmental Management 26(6):629-641.

Silliman, S.E., and D.F. Booth. 1993. Analysis of time-series measurements of sediment temperature for identification of gaining vs. losing portions of Juday Creek, Indiana. Journal of Hydrology 146:131-148.

Tipping, R.G., A.C. Runkel, E.C. Alexander Jr., S.C. Alexander, J.A. Green. 2006. Evidence for hydraulic heterogeneity and anisotropy in the mostly carbonate Prairie du Chien Group, southeastern Minnesota, USA. Sedimentary Geology 184(3-4): 305-330.

Trimble, S. W. 1999. Decreased rates of alluvial sediment storage in the Coon Creek Basin, Wisconsin, 1975-93. Science 285(5431):1244-1246.

USDA-NRCS (US Department of Agriculture-Natural Resources Conservation Service). 2009. Web soil survey download. http://websoilsurvey.nrcs.usda.gov/app/. Accessed 2009 January.

US EPA (US Environmental Protection Agency). 2003. National management measures to control nonpoint source pollution from agriculture. EPA Report 841-B-03-004. Washington, DC: US Environmental Protection Agency. http://water.epa.gov/polwaste/nps/agriculture/agmm_index.cfm.

USGS (US Geological Survey). 2009. National Map Viewer and Download. http://nationalmap.gov/viewer.html. Accessed 2009 January.

Vaché, K.B., J. M. Eilers, M. V. Santelmann. 2002. Water quality modeling of alternative agricultural scenarios in the U.S. Corn Belt. Journal of the American Water Resources Association 38(3):773-787.

Walker, W.W. 1996. Simplified procedures for eutrophication assessment and prediction: User manual, instruction report W-96-2. Vicksburg, MS: Army Engineer Waterways Experiment Station.

Wang, X., A.M. Melesse, W. Yang. 2006. Influences of potential evapotranspiration estimation methods on SWAT's hydrologic simulation in a northwestern Minnesota watershed. Transactions of the ASABE 49(6):1755-1771.

Warren, S.D., M.B. Nevill, W.H. Blackburn, and N.E. Garza. 1986. Soil response to trampling under intensive rotational grazing. Soil Science Society of America Journal 50(5): 13361341. 
763 Wilson, G.L. 2012. Grass-fed beef in Southeast Minnesota: Evaluating potential water quality 764 improvements with increased grass-fed beef production. Master's thesis, University of 765 Minnesota. 


\section{FIGURES}

Figure 1

768

Location and important features of the South Branch of the Root River (SBRR) watershed. Maps show a)

769 hydrologic features, and locations of weather and streamflow measurements; b) predominant landuse/land-cover; c) watershed slope; and d) location of select management practices (manure application

771 and alternative grazing land-use scenarios). The watershed boundary and stream network were

772 developed from a 30-m digital elevation model (DEM). Water and wetlands compose $0.6 \%$ of the land

773 cover in the watershed, but were excluded from the figure for visualization purposes.
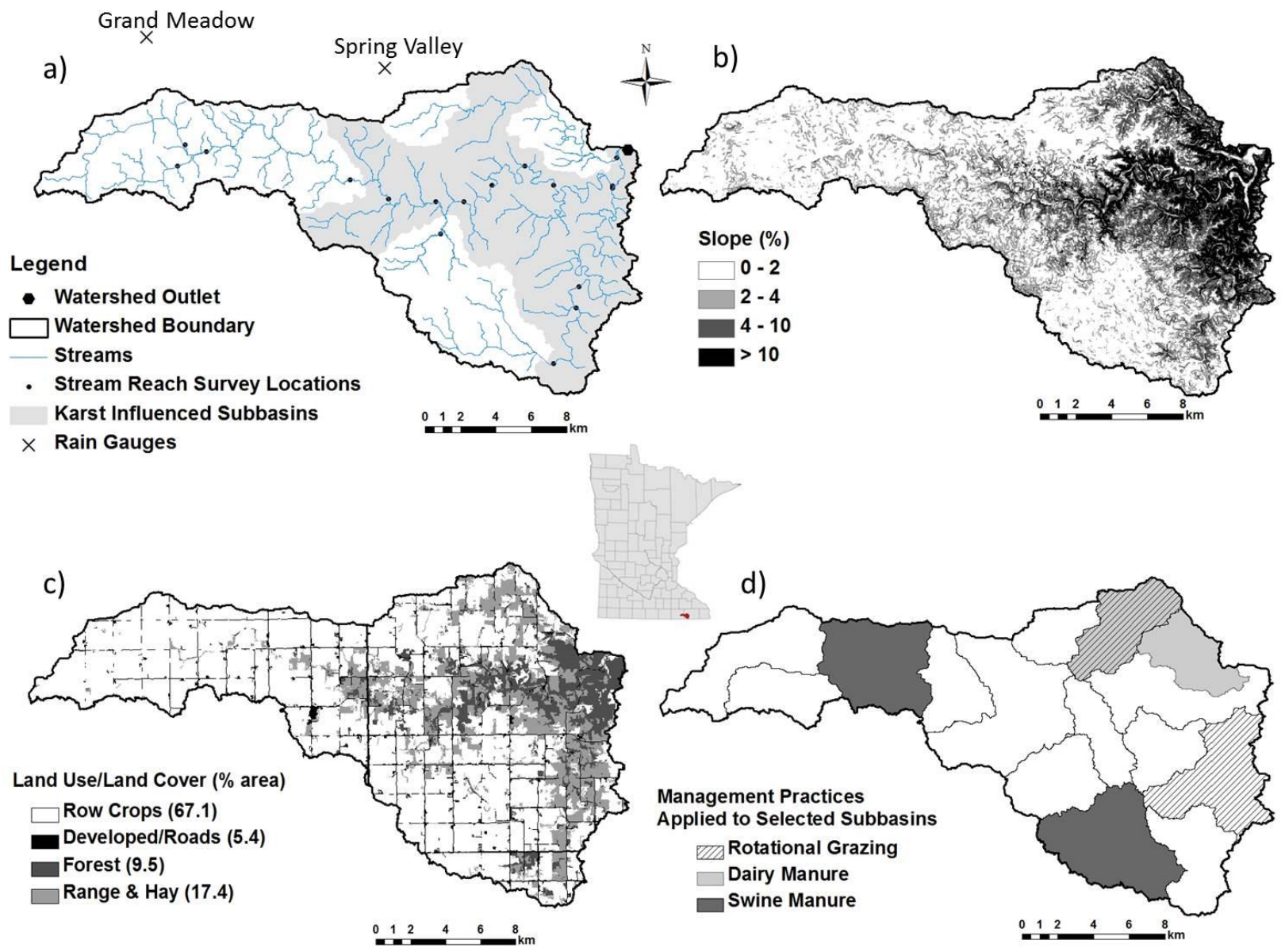
Table 1

778 Parameters used for calibration and validation of the SWAT model in the South Branch Root River 779 watershed. Most parameters were applied to all HRUs; those that varied on an HRU basis are indicated by "varies."

\begin{tabular}{|c|c|c|c|}
\hline Parameter & Description & Default & Calibrated Value \\
\hline TIMP.bsn & Snow temperature lag factor & 1 & 0 \\
\hline \multirow[t]{2}{*}{ PET method.bsn } & Methods for estimating potential ET (c.f & Penman & Hargreaves \\
\hline & Wang et al. 2006) & Monteith & \\
\hline ESCO.bsn & Soil evaporation compensation factor & 0.95 & 0.60 \\
\hline EPCO.bsn & Plant uptake compensation factor & 1 & 0.95 \\
\hline CN_FROZ.bsn & $\begin{array}{l}\text { Allows application of curve number approach } \\
\text { to frozen soils }\end{array}$ & Inactive & Active \\
\hline Crack Flow.bsn & Simulates crack development in soils & Inactive & Active \\
\hline SURLAG.bsn & Surface runoff lag coefficient & 4 & 3 \\
\hline PRF.bsn & $\begin{array}{l}\text { Peak rate adjustment factor for sediment } \\
\text { routing }\end{array}$ & 1 & 0.8 \\
\hline SPCON.bsn & Sediment entrainment factor- linear & 0.0001 & 0.001 \\
\hline EPEXP.bsn & Sediment entrainment factor- exponent & 1 & 1.5 \\
\hline CMN.bsn & Rate factor for humus mineralization & 0.0003 & 0.002 \\
\hline CDN.bsn & Denitrification exponential rate coefficient & 0 & 0.05 \\
\hline SDNCO.bsn & Denitrification threshold water coefficient & 0 & 0.95 \\
\hline \multirow[t]{3}{*}{ OV_N.hru } & $\begin{array}{l}\text { Manning's roughness coefficient for overland } \\
\text { flow }\end{array}$ & & \\
\hline & Annual crop fields & 0.14 & 0.4 \\
\hline & All other land-use & 0.14 & 0.25 \\
\hline \multirow[t]{3}{*}{ DEP_IMP.hru } & $\begin{array}{l}\text { Depth to impervious layer in soil profile } \\
(\mathrm{mm})\end{array}$ & & \\
\hline & A and B soils & Inactive & 3750 \\
\hline & $\mathrm{A} / \mathrm{D}, \mathrm{B} / \mathrm{D}, \mathrm{C}$ and $\mathrm{D}$ soils & Inactive & 1500 \\
\hline CANMX.hru & Maximum canopy storage (mm) & 0 & 4 \\
\hline GW_DELAY.gw & Groundwater delay time (days) & 31 & $1 *$ \\
\hline \multirow[t]{3}{*}{ Alpha_BF.gw } & $\begin{array}{l}\text { Base flow recession constant, groundwater } \\
\text { response to changes in recharge }\end{array}$ & & \\
\hline & Non-karst subbasins & 0.048 & 0.08 \\
\hline & Karst subbasins & 0.048 & 0.64 \\
\hline Rchrg_dp.gw & Deep aquifer percolation fraction & 0.05 & 0.1 \\
\hline GWQMIN.gw & $\begin{array}{l}\text { Threshold depth of water in shallow aquifer } \\
\text { required for return flow to occur }\end{array}$ & 0 & 150 \\
\hline FRSD.mgt & Initial age of trees & 0 & 50 \\
\hline $\mathrm{Cn} 2 . \mathrm{mgt}$ & SCS curve number & Varies & $\begin{array}{l}\text { Decreased by } 20 \% \text { (from } \\
\text { default values) }\end{array}$ \\
\hline \multirow[t]{3}{*}{ Ch_K2.rte } & $\begin{array}{l}\text { Hydraulic conductivity of channel bed } \\
\text { material }\left(\mathrm{mm} \mathrm{hr}^{-1}\right)\end{array}$ & & \\
\hline & Non-karst subbasins & 0 & 37 \\
\hline & Karst subbasins & 0 & 66 \\
\hline CH_W.rte & Channel width at bankful conditions (m) & Varies & Measured value, varies \\
\hline CH_D.rte & Channel depth at bankful conditions (m) & Varies & Measured value, varies \\
\hline W/D.rte & Width/depth ratio & Varies & Measured value, varies \\
\hline CH_N2.rte & $\begin{array}{l}\text { Manning's roughness coefficient for channel } \\
\text { flow }\end{array}$ & 0.014 & Measured value, varies \\
\hline
\end{tabular}

*For karst subbasins only. 
Table 3

784 Description of each alternative scenario simulated in SWAT. Alternative conservation management

785 scenarios include management practices applied to existing cropland with the goal of reducing sediment

786 and phosphorus losses from fields. The land-use change scenarios simulated cropland areas converted

787 into pasture for management intensive rotational grazing of beef cattle.

\begin{tabular}{|c|c|c|}
\hline Alternative Scenario & Description & $\begin{array}{l}\% \text { of Watershed } \\
\text { Area in } \\
\text { Treatment }\end{array}$ \\
\hline \multicolumn{3}{|c|}{ Conservation Management Scenarios } \\
\hline ConsTill 25 & $\begin{array}{l}\text { Conservation tillage applied to } 25 \% \text { of cropland in a } \\
\text { non-targeted approach }\end{array}$ & 17 \\
\hline ConsTill 4 & $\begin{array}{l}\text { Conservation tillage applied to all cropland with slope } \\
\text { greater than } 4 \%\end{array}$ & 8.4 \\
\hline Filter4 & $\begin{array}{l}\text { 10m filter strip on all cropland with a slope greater } \\
\text { than } 4 \%\end{array}$ & 8.4 \\
\hline CovCrop4 & $\begin{array}{l}\text { Cover crops on all cropland with a slope greater than } \\
4 \% \text {; no manure on croplands with slope greater than } \\
4 \%\end{array}$ & 8.4 \\
\hline $\begin{array}{l}\text { CovCrop4- } \\
\text { ConsTill100 }\end{array}$ & $\begin{array}{l}\text { Cover crops on all cropland with a slope greater than } \\
4 \% \text { and conservation tillage on all remaining } \\
\text { cropland; no manure on croplands with slope greater } \\
\text { than } 4 \%\end{array}$ & 67 \\
\hline $\begin{array}{l}\text { CovCropFilter4- } \\
\text { ConsTill } 100\end{array}$ & $\begin{array}{l}\text { Cover crops and filter strips on all cropland with a } \\
\text { slope greater than } 4 \% \text {; conservation tillage on all } \\
\text { remaining cropland; no manure on croplands with } \\
\text { slope greater than } 4 \%\end{array}$ & 67 \\
\hline \multicolumn{3}{|l|}{ Land-Use Change Scenarios } \\
\hline GLU-steep & $\begin{array}{l}\text { Cropland on slopes greater than } 4 \% \text { converted into } \\
\text { pasture for grazing in select subbasins }\end{array}$ & 2.6 \\
\hline GLU-CPI & $\begin{array}{l}\text { Cropland with low crop productivity indices } \\
\text { converted into pasture for grazing in select subbasins }\end{array}$ & 2.6 \\
\hline GLU- random & $\begin{array}{l}\text { Cropland, chosen at random, converted into pasture } \\
\text { for grazing in select subbasins }\end{array}$ & 2.6 \\
\hline
\end{tabular}




\section{Table 3}

791 Calibration (cal) and validation (val) results for the SBRR watershed. Observed and simulated

792 streamflow, sediment, and total phosphorus are average monthly values.

\begin{tabular}{|c|c|c|c|c|c|c|}
\hline \multirow[b]{2}{*}{$\begin{array}{l}\text { Performance } \\
\text { Measures }\end{array}$} & \multicolumn{2}{|c|}{$\begin{array}{c}\text { Streamflow } \\
\left(\mathrm{m}^{3} \mathrm{sec}^{-1}\right)\end{array}$} & \multicolumn{2}{|c|}{$\begin{array}{c}\text { Sediment } \\
\text { (tons) }\end{array}$} & \multicolumn{2}{|c|}{$\begin{array}{c}\text { Phosphorus } \\
\text { (kg) }\end{array}$} \\
\hline & Cal & Val & Cal & Val & Cal & Val \\
\hline Observed & 3.18 & 3.39 & 998 & 1,477 & 1,820 & 2,544 \\
\hline Simulated & 3.27 & 3.24 & 811 & 1,403 & 1,371 & 2,191 \\
\hline Monthly NSE & 0.76 & 0.78 & 0.32 & 0.75 & 0.53 & 0.67 \\
\hline
\end{tabular}


794 Observed and simulated monthly a) streamflow, b) sediment, and c) total phosphorus at the outlet of the 795 South Branch Root River watershed (SBRR). Data gaps in the observed measurements occur when 796 monitoring equipment was not deployed (usually a result of winter ice cover).
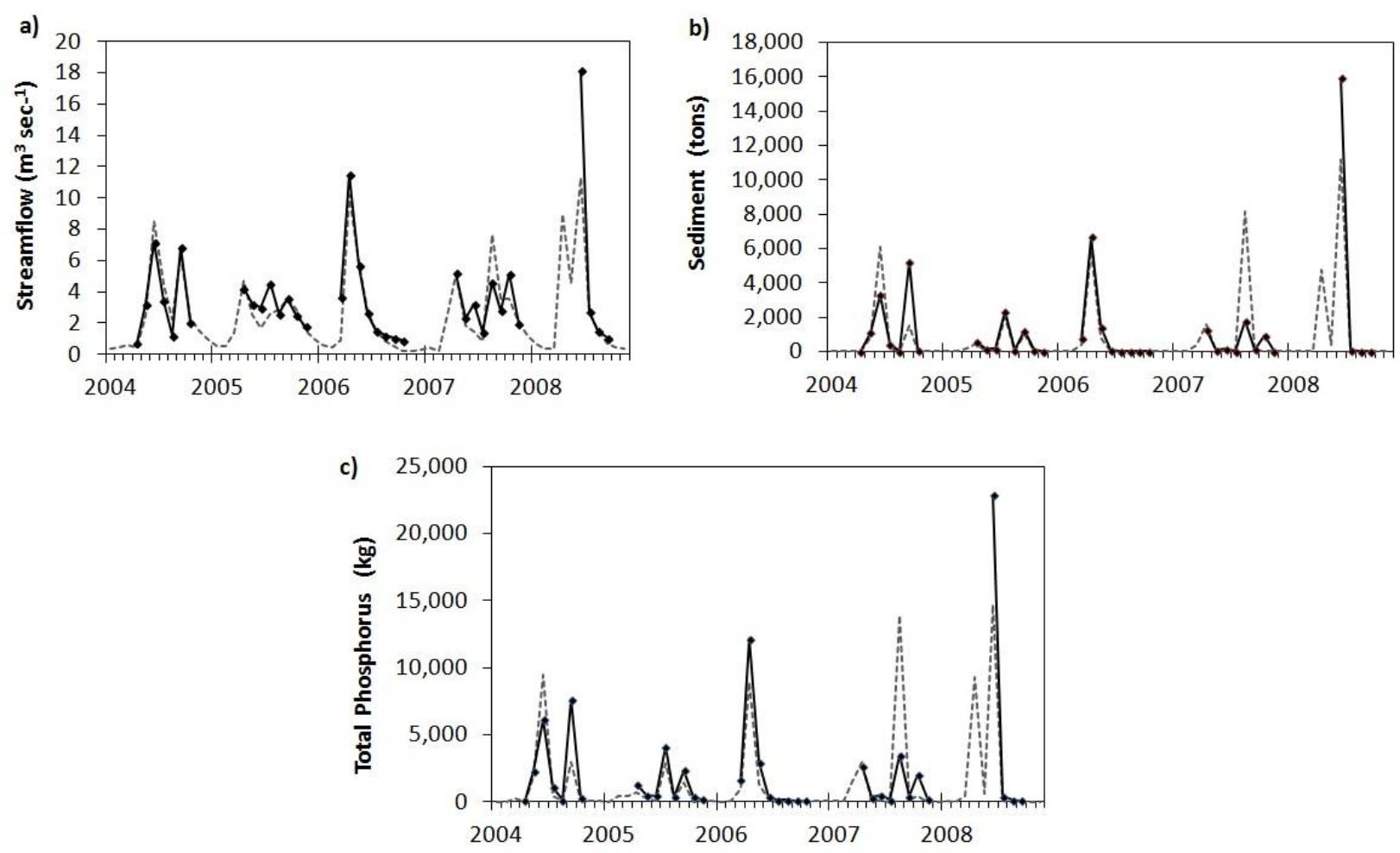

797

-----Predicted

798

799 
Figure 3

802 Cumulative upland a) sediment and b) total phosphorus yield, plotted as a function of cumulative

803 watershed area for the SBRR. One fourth of the total watershed area accounted for $75 \%$ of sediment

804 loads and 64\% of TP loads. Sediment and TP loads from developed/roads and hay/rangeland land-uses

805 make up the rest of the cumulative upland yields. (Developed roads are indicated by the light colored line

806 on the sediment figure; the description was not included in the figure due to space restrictions.)

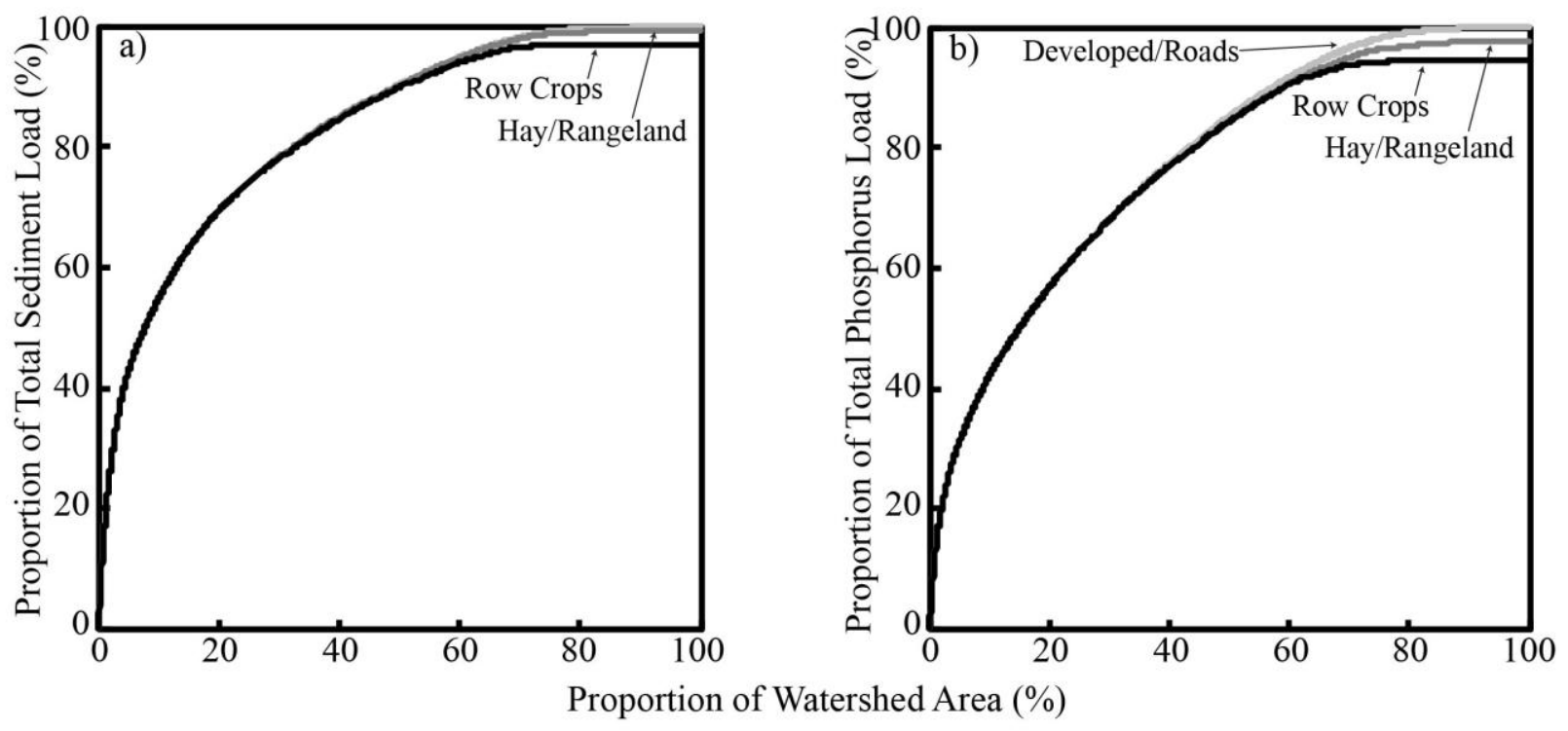




\section{Figure 4}

810 Percent change in simulated annual sediment load (averaged over the 5-year simulation period) from the

811 HRUs during alternative scenarios relative to baseline scenario. (X-axis terms are described in table 3 ).

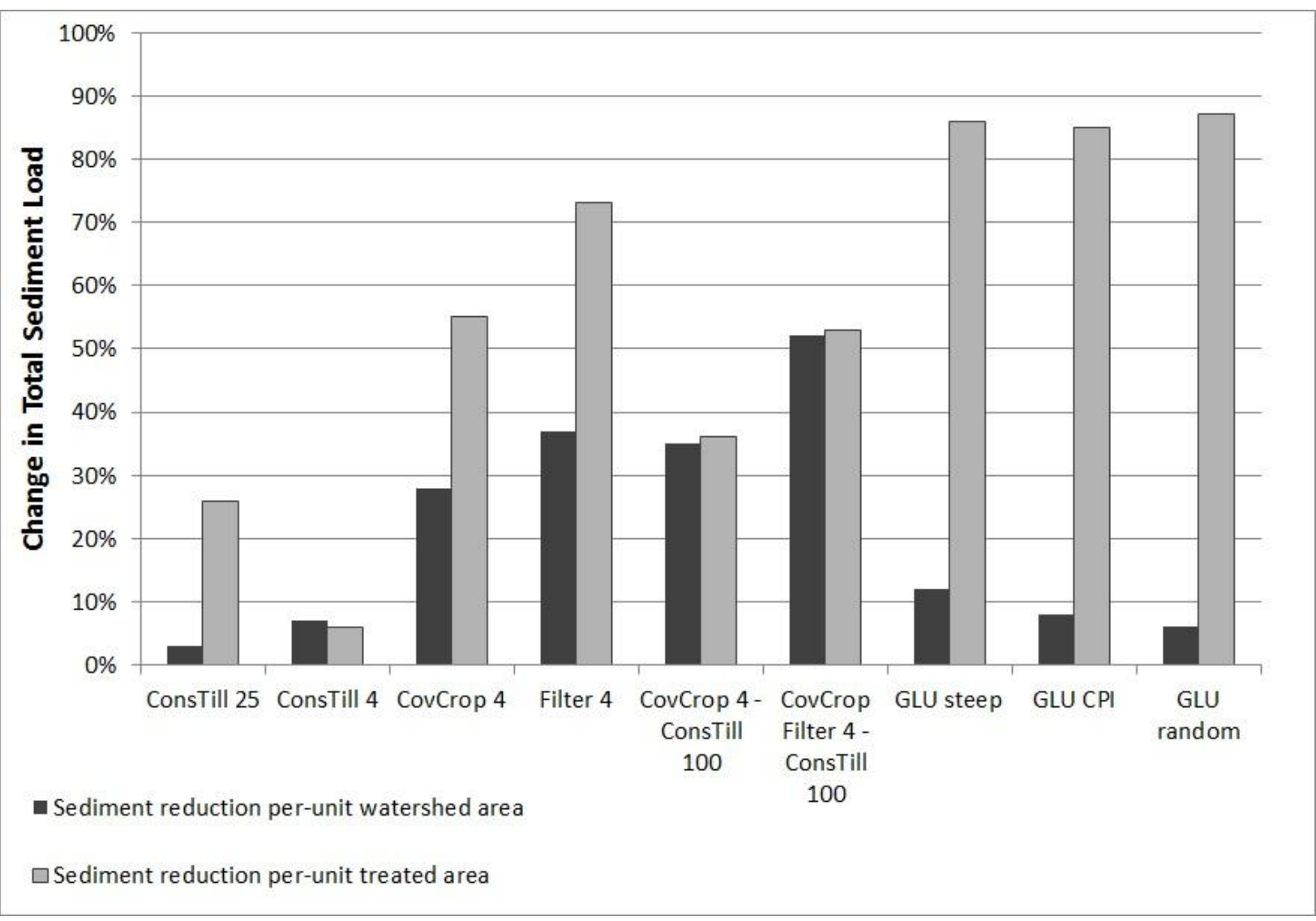




\section{Figure 5}

815 Percent change in simulated annual total phosphorus load (averaged over the 5-year simulation period)

816 from the HRUs during alternative scenarios relative to baseline scenario. (X-axis terms are described in 817 table 3).

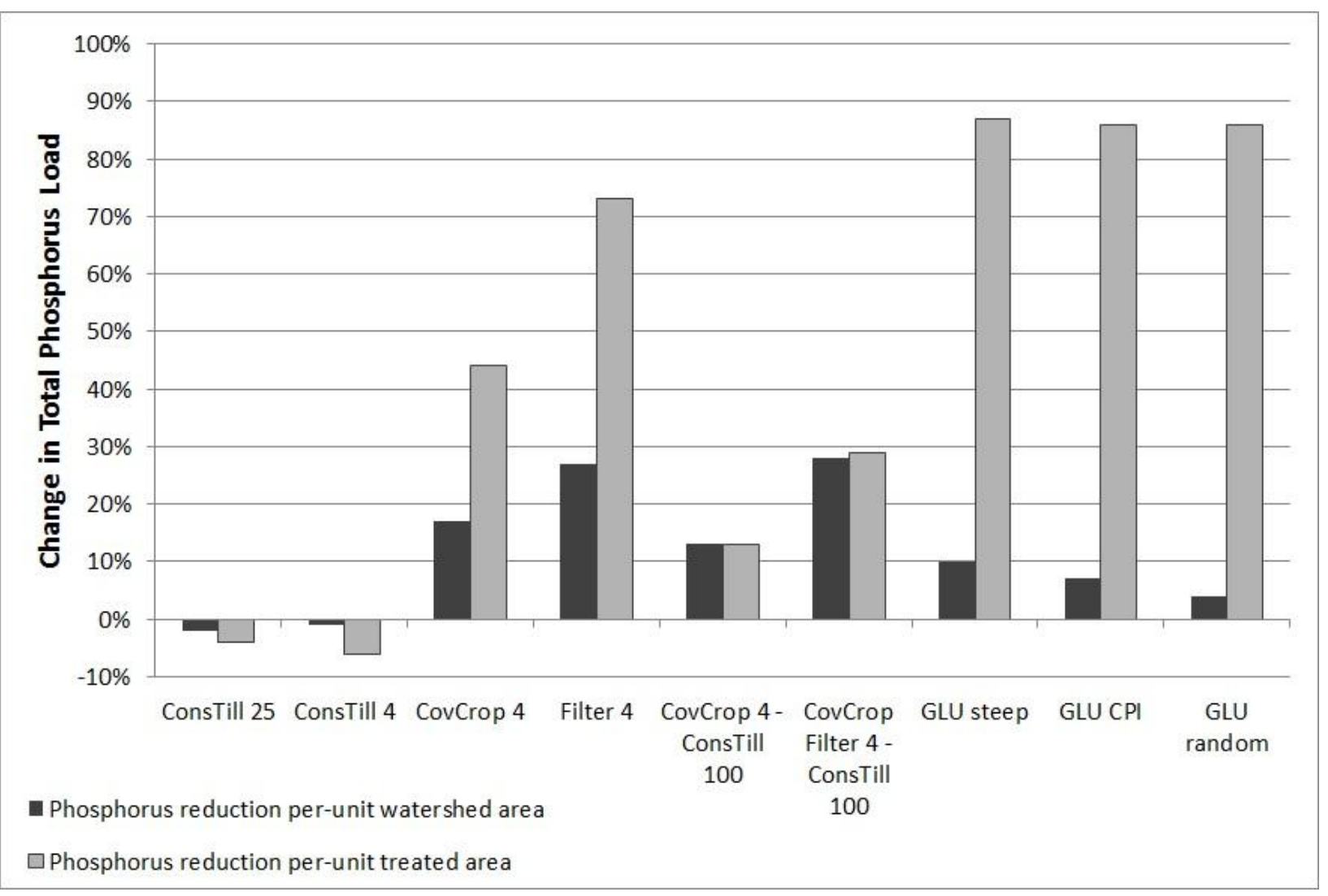

